\title{
CONTRIBUTION OF NITROGEN AND PHOSPHATE FERTILIZER IN THE INITIAL GROWTH OF Toona ciliata AND Eucalyptus grandis
}

\author{
Clovis Orlando Da Ros ${ }^{1 *}$, Edison Rogerio Perrando ${ }^{2}$, Lucindo Somavilla ${ }^{1}$, Kauana Engel $^{3}$, Marcela de Melo \\ Torchelsen $^{1}$, Rodrigo Ferreira da Silva ${ }^{1}$ \\ ${ }^{1}$ Federal University of Santa Maria (UFSM), Frederico Westphalen Campus, Department of Agronomic and Environmental Sciences, \\ Frederico Westphalen, Brazil - clovisdaros@gmail.com*, lucindosomavilla@hotmail.com, mtorchelsen@hotmail.com, \\ rodrigosilva@smail.ufsm.br \\ ${ }^{2}$ Federal University of Santa Maria (UFSM), Frederico Westphalen Campus, Department of Forest Engineering, Frederico Westphalen, \\ Brazil - edison.perrando@ufsm.br \\ ${ }^{3}$ State University of the Midwest (UNICENTRO), Irati Campus, Graduate Program in Forest Sciences, Brazil - kauanaeg@ gmail.com
}

Received for publication: 13/03/2017 - Accepted for publication: 25/05/2018

\begin{abstract}
The growth of forest species is affected by nutritional restrictions. Therefore, the objective of this study was to evaluate the contribution of nitrogen and phosphate fertilization to the initial growth of forest species implanted in field. For this purpose, two experiments were carried out for 11 months, using a randomized complete block design with four replications, in a 2 x 4 factorial arrangement: two forest species (Toona ciliata and Eucalyptus grandis), four nitrogen doses in Experiment $\mathrm{I}\left(0,25,50\right.$ and $75 \mathrm{~kg} \mathrm{ha}^{-1}$ of $\left.\mathrm{N}\right)$ and four phosphorus doses in experiment II $\left(0,50,100\right.$ and $150 \mathrm{~kg} \mathrm{ha}^{-1}$ of $\left.\mathrm{P}_{2} \mathrm{O}_{5}\right)$. The evaluated parameters were: plant height, diameter at breast height and leaf concentration of nutrients. The data were submitted to analysis of variance. Adjusted regression models were based on the applied amounts of nutrients. The contribution of nitrogen fertilization to growth in height and diameter was equal in forest species, indicating the dose of $47 \mathrm{~kg} \mathrm{ha}^{-1}$ of nitrogen with higher growth in the average of the two parameters evaluated. Phosphate fertilization showed no response in the growth of forest species due to the adequate phosphorus content of the soil in which the experiment was conducted. The leaf concentrations of nitrogen and phosphorus were not altered by the respective nutrient doses applied in the forest species. However, higher nutrient concentrations were observed in T. ciliata, indicating higher nutritional requirement compared to $E$. grandis.

Keywords: Plant height, nitrogen, phosphorus, Australian cedar, eucalyptus.
\end{abstract}

\section{Resumo}

Contribuição da adubação nitrogenada e fosfatada no crescimento inicial de Toona ciliata e Eucalyptus grandis. O crescimento de espécies florestais é afetado por restrições nutricionais. Diante disso, este trabalho teve por objetivo avaliar a contribuição da adubação nitrogenada e fosfatada no crescimento inicial de espécies florestais implantadas a campo. Para isso, foram conduzidos dois experimentos, durante 11 meses, utilizandose o delineamento experimental em blocos ao acaso, com quatro repetições, em arranjo fatorial 2 x 4: duas espécies florestais (Toona ciliata e Eucalyptus grandis), quatro doses de nitrogênio no experimento I ( $0,25,50$ e $\left.75 \mathrm{~kg} \mathrm{ha}^{-1} \mathrm{de} \mathrm{N}\right)$ e quatro doses de fósforo no experimento II $\left(0,50,100\right.$ e $\left.150 \mathrm{~kg} \mathrm{ha}^{-1} \mathrm{de}_{2} \mathrm{O}_{5}\right)$. Os parâmetros avaliados foram: altura da planta, diâmetro à altura do peito e concentração foliar de nutrientes. Os dados foram submetidos à análise de variância, e modelos de regressão foram ajustados com base nas quantidades aplicadas de nutrientes. A contribuição da adubação nitrogenada no crescimento em altura e em diâmetro foi igual para as duas espécies florestais, indicando a dose de $47 \mathrm{~kg} \mathrm{ha}^{-1}$ de nitrogênio com maior crescimento na média dos dois parâmetros avaliados. A adubação fosfatada não apresentou resposta ao crescimento das plantas para as duas espécies florestais devido à concentração adequada de fósforo no solo em que o experimento foi conduzido. As concentrações foliares de nitrogênio e fósforo não foram alteradas pelas doses dos respectivos nutrientes aplicadas nas duas espécies florestais. No entanto, foram observadas maiores concentrações dos nutrientes em $T$. ciliata, indicando sua maior exigência nutricional em comparação com E. grandis.

Palavras-chave: Altura da planta, nitrogênio, fósforo, cedro australiano, eucalipto.

\section{INTRODUCTION}

Species of the genus Eucalyptus stand out due to their high flexibility to edaphoclimatic conditions. In the southern region of Brazil, along with Pinus, it occupies the second largest area of planted forests in the country due to its good features of adaptability, growth and productivity (ABRAF, 2013). Australian cedar (Toona ciliata M. Roem var. australis), of the family Meliaceae, native from tropical regions of Australia, is another species that

FLORESTA, Curitiba, PR, v. 49, n. 1, p. 001-010, jan/mar 2019

Da Ros. C. O et.al.

ISSN eletrônico 1982-4688

DOI: 10.5380 / rf.v49 i1.51174 
has been increasing the planting area in Brazil, mainly in the South of Bahia and in the Southeast region, because it features rapid growth and good quality wood (VILELA; STEHLING, 2012).

Information on nutrition in Australian cedar crops is directed to the production of seedlings, and there is little field data on their growth under the edaphoclimatic conditions of the southern region of Brazil, compared to eucalyptus crops. The Australian cedar is a species that demands nutrients and it does not tolerate acid ground (BRAGA et al., 2015), being $\mathrm{N}$ (nitrogen) and P (phosphorus), the nutrients that limit most the growth of the cuttings (MORETTI et al., 2011).

The $\mathrm{N}$ availability to the forest species is related to the content of organic matter in the soil and to its mineralization rate, having a direct influence in the response to the nitrogen fertilization. The growth response of the plant in relation to the $\mathrm{N}$ application occurs in young forest cultures and cultures with a small organic matter content in its soil (GAZOLA et al., 2015). In some situations, it may occur an answer even in soils with high organic matter content, in which the low mineralization rate is not capable of meet adequately the demand for this plant nutrients (JESUS et al., 2012). In already stabilized crops, the recycling of $\mathrm{N}$ through the burlap normally takes care of the demand for $\mathrm{N}$ of the plants and the reply to the nitrogen fertilization is small or null (GAMARODRIGUES et al., 2005).

$\mathrm{P}$ is a nutrient found in low concentration in most part of Brazilian ground, mainly in grounds with high oxide texts of iron and aluminum (GUARDINI et al., 2012). Associated to the low availability in the soil, it is considered one of the nutrients that most restricts the growth of the saplings in the initial phase of production (MORETTI et al., 2011). Its nutritional deficiency causes a smaller number of levels and lateral roots and reduction in the production of biomass from the aerial part of the forest species in commercial cultures (DIAS et al., 2014; GAZOLA et al., 2015; MORETTI et al., 2015).

Studies show that the contribution of nitrogenous fertilization on plant growth varies within the same forest species, since there may be difference in the supplying of the nutrient in relation to content and rate of mineralization of organic matter in the soil (GAMMA-RODRIGUES et al., 2005; SANTANA et al., 2008). In the case of $\mathrm{P}$, the variation in the supply to the plants is related to the concentration of the original material and the adsorption to soil colloids (GUARDINI et al., 2012). Webb et al. (2000) still report that there are significant differences in the ability to absorb and translocate the nutrient. Consequently, the application of phosphate fertilization is often inefficient, regardless of the type of soil or forest species. Thus, the delimitation of the fertilization contribution on the growth of forest species is needed in studies that contribute to the definition of nutrients doses and that ensure better productivity of forest cultures. In this context, the objective of this work was to evaluate the contribution of nitrogenous and phosphate fertilizer in the initial growth of Australian cedar and eucalyptus deployed in the field.

\section{MATERIAL AND METHODS}

The study was conducted in the field in November 2013 to October 2014, in the experimental area of the Federal University of Santa Maria, Frederico Westphalen Campus, located at coordinates circumscribed $27^{\circ} 23^{\prime}$ $46^{\prime \prime} \mathrm{S}$ and $53^{\circ} 25^{\prime} 32^{\prime \prime} \mathrm{W}$. The climate of the region is subtropical humid with hot summer, Cfa type, with maximum greater than or equal to $22^{\circ} \mathrm{C}$ and minimum of colder months between -3 and $18^{\circ} \mathrm{C}$, and average annual precipitation between 1,900 and 2,200 mm (ALVARES et al., 2013). Figure 1 shows the rainfall and average monthly data of the automatic station of the 8th District of Meteorology during the conduction period of the experiment located in Frederico Westphalen ( $27^{\circ} 23^{\prime} 44.5^{\prime \prime} \mathrm{S}$ and $\left.53^{\circ} 25^{\prime} 45.9^{\prime \prime} \mathrm{W}\right), 420 \mathrm{~m}$ from the experimental area.

The ground was characterized as Oxisol (Red Latosol) (SANTOS et al., 2013), with the following attributes in the layer of 0 to $20 \mathrm{~cm}: 680 \mathrm{~g} \mathrm{~kg}^{-1}$ of clay; $\mathrm{pH}$ in water of $5.9 ; 4.9 \mathrm{mg} \mathrm{dm}^{-3}$ of P; $162 \mathrm{mg} \mathrm{dm}^{-3}$ of K$^{+} ; 6.3 \mathrm{cmol}_{\mathrm{c}}$ $\mathrm{dm}^{-3}$ of $\mathrm{Ca}^{2+} ; 3.2 \mathrm{cmol}_{\mathrm{c}} \mathrm{dm}^{-3}$ of $\mathrm{Mg}^{2+} ; 9.1 \mathrm{mg} \mathrm{dm}{ }^{-3}$ of $\mathrm{S} ; 11.2 \mathrm{mg} \mathrm{dm}{ }^{-3}$ of Cu; $2.9 \mathrm{mg} \mathrm{dm}^{-3}$ of Zn, $2.2 \mathrm{~g} \mathrm{~kg}^{-1}$ of organic matter; e $74 \%$ of saturation for bases. The levels of available nutrients in the soil were quantified according to methodologies of chemical analyses for fertility evaluation, described in Silva (2009), and use of: Mehlich-1 extractors for $\mathrm{P}$ and $\mathrm{K}$; solution $\mathrm{KCl} 1 \mathrm{~mol} \mathrm{~L}^{-1}$ for extraction of $\mathrm{Ca}$ and $\mathrm{Mg}$; phosphate solution of $\mathrm{Ca}$ to $\mathrm{S}$; e solution $\mathrm{HCl} 0.1 \mathrm{~mol} \mathrm{~L}^{-1}$ for $\mathrm{Cu}$ and $\mathrm{Zn}$.

The experimental design was of randomized blocks with four repetitions, in two experiments conducted in factorial arrangement $2 \times 4$ with two forest species: Australian cedar (Toona ciliata M. Roem var. australis) and eucalyptus (Eucalyptus grandis Hill ex Maiden). In experiment I, four doses of N (0, 25, 50 and $75 \mathrm{~kg} \mathrm{ha}^{-1}$ of $\mathrm{N})$ were tested, while in experiment II, four doses of $\mathrm{P}\left(0,50,100\right.$ and $150 \mathrm{~kg} \mathrm{ha}^{-1}$ of $\left.\mathrm{P}_{2} \mathrm{O}_{5}\right)$ were tested.

The seedlings of forest species were planted in field on November 1, 2013, in an area previously used for cultivation of beans in the no-tillage system, which remained fallow (without cultivation) in the last three years preceding the implementation of the experiment. The experimental area was mowed with tractor-brush cutter and subsequently dried out with glyphosate. Before planting, furrows were opened in the cultivation line from layer 0

FLORESTA, Curitiba, PR, v. 49, n. 1, p. 001-010, jan/mar 2019 
to $20 \mathrm{~cm}$, with the help of a chisel plough. The planting of the seedlings was performed in manually open pits in the planting furrow in the $1 \mathrm{x} 1 \mathrm{~m}$ spacing. The seedlings of forest species had seminal origin, coming from the forest nursery of the University Campus of Frederico Westphalen. The plots were set up to 25 plants, in a total area of $25 \mathrm{~m}^{2}(5 \times 5 \mathrm{~m})$ and useful area of $9 \mathrm{~m}^{2}(3 \times 3 \mathrm{~m})$, containing nine plants.

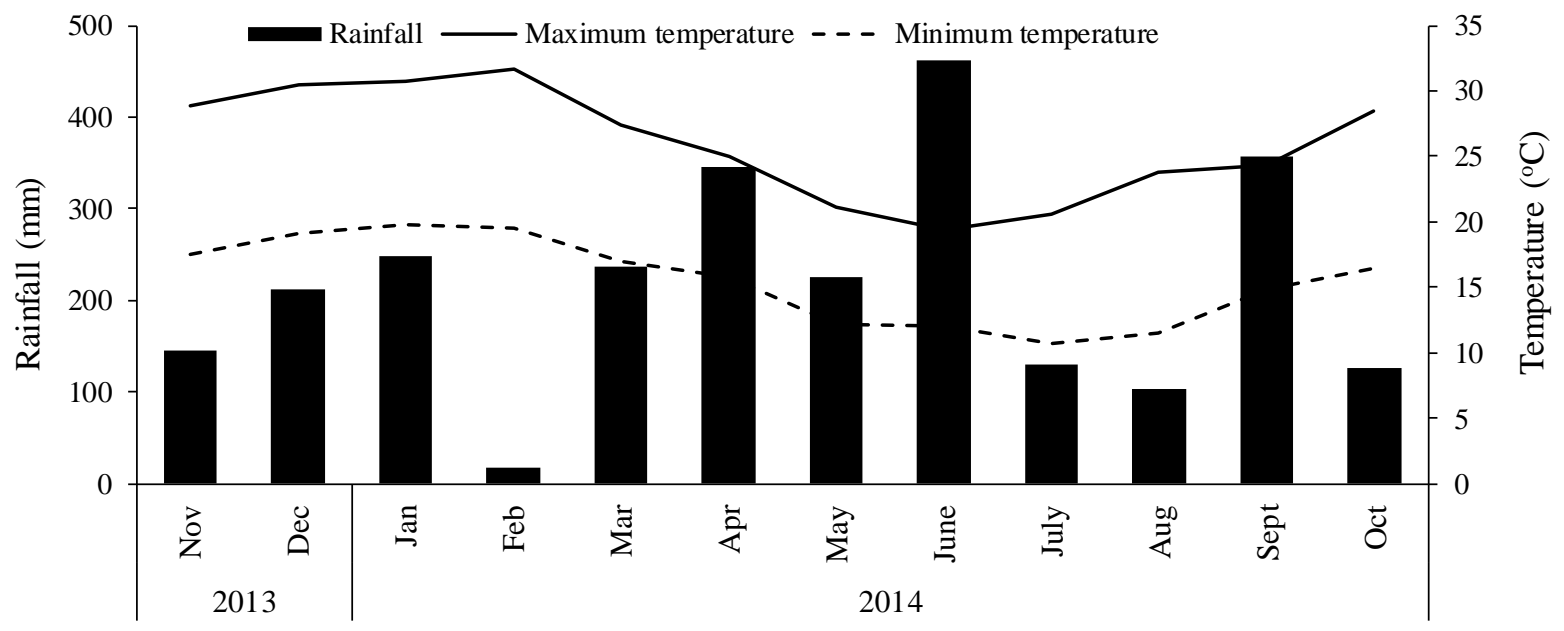

Figure 1. Monthly averages of rainfall, minimum (Tmin) and maximum (Tmax) temperatures from November 2013 to October 2014.

Figura 1. Médias mensais de precipitação pluviométrica, temperaturas mínimas (Tmin) e máximas (Tmax) no período de novembro de 2013 a outubro de 2014.

$\mathrm{N}$ doses (experiment $\mathrm{I}$ ) were applied at planting and in cover: the treatment with the dose of $25 \mathrm{~kg} \mathrm{ha}^{-1}$ of $\mathrm{N}$ was applied only at planting; the treatment dose of $50 \mathrm{~kg} \mathrm{ha}^{-1}$ was applied in two steps, half in plantation and the remainder in coverage, two months after planting; and the treatment dose of $75 \mathrm{~kg} \mathrm{ha}^{-1}$ was applied in three stages, one third being in planting and the remainder in two cover applications, two and four months after planting. In the planting, the quantity of $\mathrm{N}$ was applied at the bottom of the pit and mixed with the soil, along with a fixed dose of $100 \mathrm{~kg} \mathrm{ha}^{-1} \mathrm{P}_{2} \mathrm{O}_{5}$ in all parcels, in the form of triple superphosphate. On the cover, the $\mathrm{N}$ doses were applied in the canopy projection, on the crown and without incorporation into the soil.

The doses of P (experiment II) were applied at the bottom of the pit and mixed with the soil immediately before planting in the form of triple superphosphate, along with $25 \mathrm{~kg} \mathrm{ha}^{-1} \mathrm{of} \mathrm{N}$ in the form of urea. In the covering, two months after the plantation, had been used $25 \mathrm{~kg} \mathrm{ha}^{-1}$ of $\mathrm{N}$, applied in the projection of the canopy of the seedlings.

The nitrogen source used in the two experiments was urea. The cover fertilizations were applied in wet soil conditions and in the late afternoon so that $\mathrm{N}$ volatilization losses were minimized. The fractioning of the $\mathrm{N}$ doses was carried out with the objective of increasing the use of the nutrient by plants (CQFS-RS/SC, 2016).

In both experiments, a dose of $45 \mathrm{~kg} \mathrm{ha}^{-1}$ of $\mathrm{K}$ was applied immediately after planting, in the form of potassium chloride at the soil surface, at distance of $20 \mathrm{~cm}$ from the seedling in order to avoid damage to the root system done by the saline effect of potassium fertilization when applied in the planting pit. The amount of $\mathrm{K}$ was calculated based on the average maintenance dose indicated for the cedar and eucalyptus crops in "very high" nutrient soils, as recommended by CQFS-RS/SC (2016). The times and the amounts of nutrients applied in the treatments of the two experiments are specified in Table 1.

The ant control was conducted using granular bait, distributed within and in proximity to the experimental area. The control of invading plants was carried through with two applications of selective herbicide (HaloxifopeP-methylic -124,7 $\mathrm{g} \mathrm{L}^{-1}$ ), in the dosage of $60 \mathrm{~g} \mathrm{ha}^{-1}$ of active ingredient, and through periodic weeding, when necessary.

Plant growth in height was measured at 6, 8 and 11 months after planting. In the first evaluation, the height was measured with a ruler graduated in centimeters, while in the two subsequent reviews, digital hypsometer was used. The 11 months after planting, it was measured the diameter at breast height with dendometric ruler, 1.30 $\mathrm{m}$ above the ground. The average height and diameter at breast height were calculated based on the number of plants of the usable area of each plot (nine plants).

Up to 8 months after planting, mature leaves were collected from the upper third of the plants of the usable

FLORESTA, Curitiba, PR, v. 49, n. 1, p. 001-010, jan/mar 2019

Da Ros. C. O et.al.

ISSN eletrônico 1982-4688

DOI: 10.5380 / rf.v49 i1.51174 
area of each portion, forming a compound sample for examination of foliar $\mathrm{N}$ and $\mathrm{P}$. Quantification of nutrients was carried out after the drying of the leaves in an oven at $65^{\circ} \mathrm{C}$, until constant mass. In the dry and ground material, the concentrations of $\mathrm{N}$ and $\mathrm{P}$ were determined after wet digestion with concentrated sulfuric acid. The $\mathrm{N}$ was quantified by drag distillation (Kjeldahl semi-micro) and $\mathrm{P}$ by spectrophotometry according to methodologies for chemical analysis of plant tissue described in Silva (2009).

Table 1. Amount of nutrients applied at planting and coverage in Australian cedar and eucalyptus in the treatments with $\mathrm{N}$ and $\mathrm{P}$ doses.

Tabela 1. Quantidade de nutrientes aplicados no plantio e cobertura em cedro australiano e eucalipto nos tratamentos com doses de $\mathrm{N}$ e $\mathrm{P}$.

\begin{tabular}{|c|c|c|c|c|c|}
\hline \multirow{3}{*}{ Treatments } & \multirow{2}{*}{\multicolumn{3}{|c|}{ Plantation fertilization $\left(\mathrm{kg} \mathrm{ha}^{-1}\right)$}} & \multicolumn{2}{|c|}{ Fertilization $\left(\mathrm{kg} \mathrm{ha}^{-1}\right)$} \\
\hline & & & & \multirow{2}{*}{$\frac{2 \text { months }}{\mathrm{N}}$} & \multirow{2}{*}{$\frac{4 \text { months }}{\mathrm{N}}$} \\
\hline & $\mathrm{N}$ & $\mathrm{P}_{2} \mathrm{O}_{5}$ & $\mathrm{~K}_{2} \mathrm{O}$ & & \\
\hline Doses of $\mathrm{N}\left(\mathrm{kg} \mathrm{ha}^{-1}\right)$ & \multicolumn{5}{|c|}{ 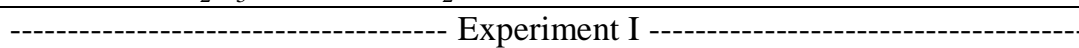 } \\
\hline 0 & 0 & 100 & 45 & 0 & 0 \\
\hline 25 & 25 & 100 & 45 & 0 & 0 \\
\hline 50 & 25 & 100 & 45 & 25 & 0 \\
\hline 75 & 25 & 100 & 45 & 25 & 25 \\
\hline Doses of $\mathrm{P}_{2} \mathrm{O}_{5}\left(\mathrm{~kg} \mathrm{ha}^{-1}\right)$ & ----- & ------ & -- Exp & ----- & \\
\hline 0 & 25 & 0 & $45^{1}$ & 25 & 0 \\
\hline 50 & 25 & 50 & 45 & 25 & 0 \\
\hline 100 & 25 & 100 & 45 & 25 & 0 \\
\hline 150 & 25 & 150 & 45 & 25 & 0 \\
\hline
\end{tabular}

The data were subjected to analysis of variance with $5 \%$ probability of error $(p \leq 0.05)$. When detected significant effects, the species were compared with each other by Tukey test and the doses by means of polynomial regression analysis. The data were analyzed in the computational statistical program Sisvar (FERREIRA, 2011).

\section{RESULTS}

\section{N Doses}

The analysis of variance showed no significant interaction between the forest species and the $\mathrm{N}$ doses for plant height, diameter at breast height, and foliar nutrient concentration, indicating the same response as that of nitrogen fertilization in two species (Table 2). Regarding main effects, there was a significant effect for the species in all evaluated parameters. For the $\mathrm{N}$ doses, there was an effect on height and diameter at breast height of plants and none to foliar nutrient concentration.

Table 2. Test $\mathrm{F}$ probability analysis of variance and coefficient of variation $(\mathrm{CV})$ of the interaction and main effect of forest species (S) and $\mathrm{N}$ doses (D) for plant height, diameter at breast height and leaf concentration of nitrogen.

Tabela 2. Probabilidade do teste F da análise de variância e coeficiente de variação (CV) da interação e dos efeitos principais das espécies florestais e doses de $\mathrm{N}$ para altura da planta, diâmetro à altura do peito e concentração foliar do nitrogênio.

\begin{tabular}{|c|c|c|c|c|}
\hline \multirow{2}{*}{ Parameter evaluated } & \multirow{2}{*}{$\begin{array}{l}\text { Interaction } \\
\text { (S x D) }\end{array}$} & \multicolumn{2}{|c|}{ Main effect } & \multirow{2}{*}{$\begin{array}{l}\text { CV } \\
(\%)\end{array}$} \\
\hline & & Species $(\mathrm{S})$ & Doses (D) & \\
\hline Height -6 months & 0.9430 & $0.0000 *$ & $0.0034 *$ & 5.8 \\
\hline Height -8 months & 0.9464 & $0.0000 *$ & $0.0024 *$ & 7.3 \\
\hline Height -11 months & 0.5103 & $0.0000 *$ & $0.0478 *$ & 8.8 \\
\hline Diameter at breast height -11 months & 0.6923 & $0.0000^{*}$ & $0.0923 *$ & 9.2 \\
\hline Leaf concentrations of $\mathrm{N}-8$ months & 0.7339 & $0.0002^{*}$ & 0.1426 & 7.8 \\
\hline
\end{tabular}

* Significant F-test $(\mathrm{p} \leq 0.05)$.

When analyzing the two species, it is observed a greater growth in eucalyptus height compared to the Australian cedar (Table 3). At 11 months of age, the heights of the eucalyptus and Australian cedar were 4.7 and $3.3 \mathrm{~m}$, respectively. The diameter at breast height was also greater in eucalyptus, with $1.6 \mathrm{~cm}$ of difference compared to Australian cedar. Foliar N concentration was 22.1 and $24.7 \mathrm{~g} \mathrm{~kg}^{-1}$ in eucalyptus and Australian cedar, respectively. Unlike the height and diameter at breast height, foliar $\mathrm{N}$ concentration was greatest in Australian cedar compared to eucalyptus. 
Table 3. Plant height, diameter at breast height and leaf nitrogen concentration in plants of Australian cedar and eucalyptus.

Tabela 3. Altura da planta, diâmetro à altura do peito e concentração foliar de nitrogênio nas plantas de cedro australiano e eucalipto.

\begin{tabular}{lcc}
\hline \multicolumn{1}{c}{ Parameters evaluated } & Australian cedar & Eucalyptus \\
\hline Plant height $(\mathrm{m})-6$ months & $2.2 \mathrm{~b}^{(1)}$ & $2.8 \mathrm{a}$ \\
Plant height $(\mathrm{m})-8$ months & $2.6 \mathrm{~b}$ & $3.4 \mathrm{a}$ \\
Plant height $(\mathrm{m})-11$ months & $3.3 \mathrm{~b}$ & $4.7 \mathrm{a}$ \\
Diameter at breast height $(\mathrm{cm})-11$ months & $3.1 \mathrm{~b}$ & $4.7 \mathrm{a}$ \\
Leaf concentration of N $\left(\mathrm{g} \mathrm{kg}^{-1}\right)-8$ months & $24.7 \mathrm{a}$ & $22.1 \mathrm{~b}$ \\
\hline
\end{tabular}

(1) Averages not followed by the same letter, in the line, differ by the test of Tukey $(\mathrm{p} \leq 0.05)$.

The reply to the nitrogen fertilization of the two-forest species presented regression adjustment of quadratic order for height and diameter at breast height, with small variation in the dose of maximum growth between the two evaluated parameters and at the different periods of evaluation (Figure 2).
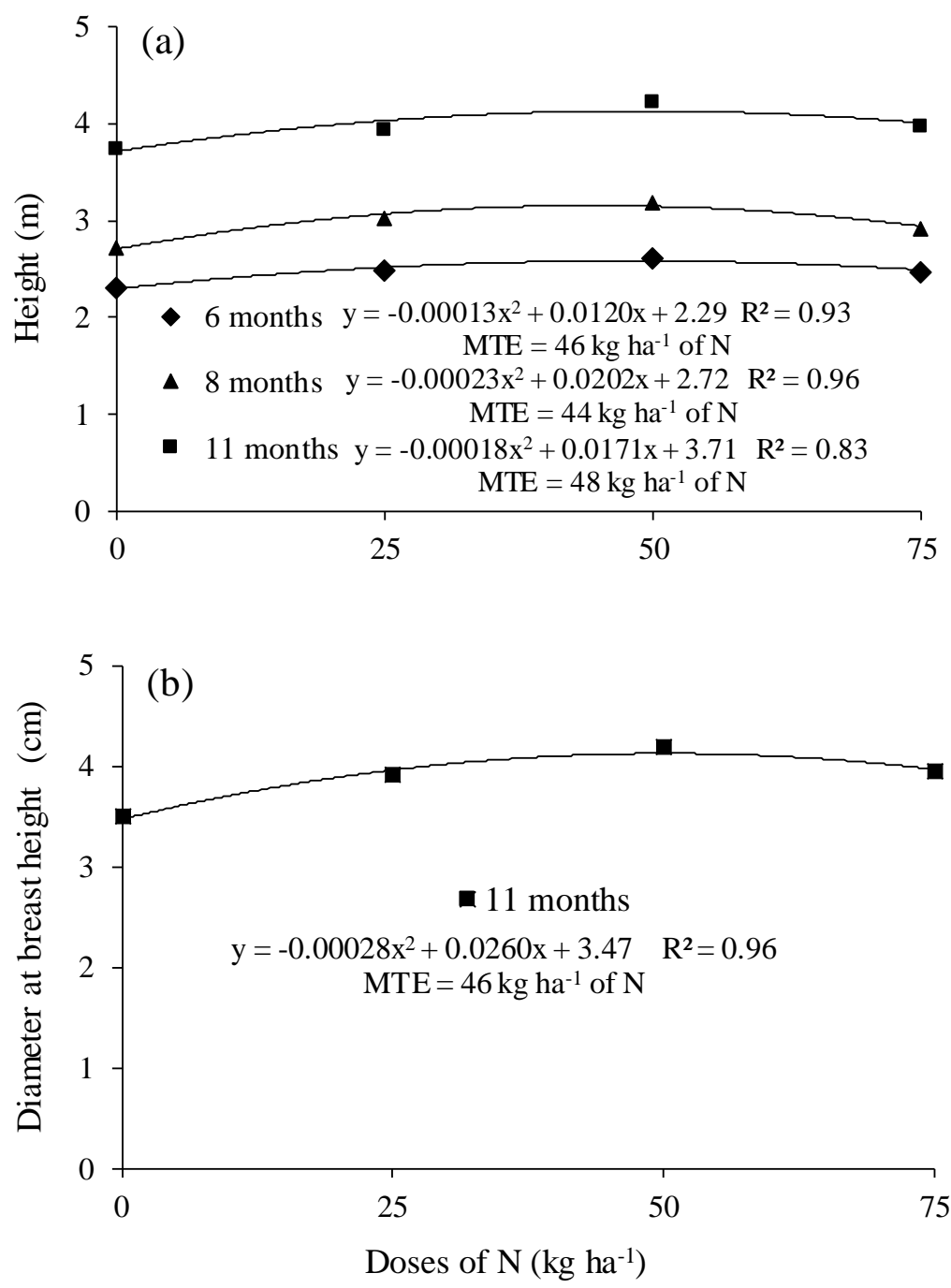

Figure 2. Height (a) and diameter at breast height (b) of the Australian cedar and eucalyptus plants depending on the nitrogen doses. Average of both forest species. MTE: maximum technical efficiency.

Figura 2. Altura (a) e diâmetro à altura do peito (b) das plantas de cedro australiano e eucalipto em função das doses de nitrogênio. Média das duas espécies florestais.

The maximum growth dose in height varied between 44 and $48 \mathrm{~kg} \mathrm{ha}^{-1}$ of $\mathrm{N}$ at the three periods of evaluation (Figure 2A) and went from $46 \mathrm{~kg} \mathrm{ha}^{-1}$ to the diameter at breast height 11 months after the plantation

FLORESTA, Curitiba, PR, v. 49, n. 1, p. 001-010, jan/mar 2019

Da Ros. C. O et.al.

ISSN eletrônico 1982-4688

DOI: 10.5380 / rf.v49 i1.51174 
(Figure 2B). Considering the two parameters evaluated at 11 months, the dose of maximum technical efficiency was, on average, of $47 \mathrm{~kg} \mathrm{ha}^{-1}$ of $\mathrm{N}$, representing an increase of $12 \%$ in relation to the treatment without nitrogen fertilization.

\section{P Doses}

The analysis of variance showed no significant interaction between the forest species and the $\mathrm{P}$ doses for plant height, diameter at breast height and foliar nutrient concentration, indicating the same response as that of nitrogen fertilization in two species (Table 4). Regarding main effects, there was a significant effect for the forest species only. Unlike nitrogenous fertilization, there was no response to doses of $\mathrm{P}$ for height, diameter at breast height and foliar concentration.

Table 4. Test F probability analysis of variance and coefficient of variation (CV) of the interaction and main effect of forest species (S) and $\mathrm{P}$ doses (D) for plant height, diameter at breast height and leaf phosphorus concentration.

Tabela 4. Probabilidade do teste F da análise da variância e coeficiente de variação (CV) da interação e dos efeitos principais das espécies florestais e doses de $\mathrm{P}$ para altura da planta, diâmetro à altura do peito e concentração foliar do fósforo.

\begin{tabular}{lcccc}
\hline \multirow{2}{*}{ Parameter evaluated } & Interaction & \multicolumn{2}{c}{ Main effect } & CV \\
\cline { 3 - 4 } & $(\mathrm{S} \times \mathrm{D})$ & Species $(\mathrm{S})$ & Doses $(\mathrm{D})$ & $(\%)$ \\
\hline Height -6 months & 0.7867 & $0.0000^{*}$ & 0.2106 & 9.2 \\
Height -8 months & 0.9824 & $0.0000^{*}$ & 0.3091 & 10.3 \\
Height -11 months & 0.9442 & $0.0000^{*}$ & 0.1831 & 9.0 \\
Diameter at breast height -11 months & 0.2622 & $0.0000^{*}$ & 0.7811 & 9.4 \\
Leaf concentration of P-8 months & 0.0816 & $0.0000^{*}$ & 0.0932 & 9.3 \\
\hline
\end{tabular}

* Significant $\mathrm{F}$ test $(\mathrm{p} \leq 0.05)$

The results for plant height and diameter at breast height of both species in the 11-month planting period were like those of the experiment with $\mathrm{N}$ doses, with lower growth of Australian cedar in all evaluation periods compared to eucalyptus (Table 5). At 11 months of age, the heights of the eucalyptus and Australian cedar were 4.7 and $3.1 \mathrm{~m}$, respectively. The diameter at breast height was also bigger in eucalyptus, with $1.6 \mathrm{~cm}$ of difference compared to Australian cedar.

The concentrations of $\mathrm{P}$ in leaves of both eucalyptus and Australian cedar were not altered by the phosphate fertilization, with average values 1.4 and $2.4 \mathrm{~g} \mathrm{~kg}^{-1}$, respectively. It is observed that the P concentration in Australian cedar leaves was higher in comparison to eucalyptus.

Table 5. Plant height, diameter at breast height and leaf phosphorus concentration in plants of Australian cedar and eucalyptus.

Tabela 5. Altura da planta, diâmetro à altura do peito e concentração foliar de fósforo nas plantas de cedro australiano e eucalipto.

\begin{tabular}{lcc}
\hline \multicolumn{1}{c}{ Parameters evaluated } & Australian cedar & Eucalyptus \\
\hline Plant height $(\mathrm{m})-6$ months & $2.2 \mathrm{~b}^{(1)}$ & $2.7 \mathrm{a}$ \\
Plant height $(\mathrm{m})-8$ months & $2.6 \mathrm{~b}$ & $3.4 \mathrm{a}$ \\
Plant height $(\mathrm{m})-11$ months & $3.3 \mathrm{~b}$ & $4.6 \mathrm{a}$ \\
Diameter at breast height $(\mathrm{cm})-11$ months & $3.1 \mathrm{~b}$ & $4.7 \mathrm{a}$ \\
Foliar concentrations of P $\left(\mathrm{g} \mathrm{kg}^{-1}\right)-8$ months & $2.4 \mathrm{a}$ & $1.4 \mathrm{~b}$ \\
\hline
\end{tabular}

(1) Averages not followed by the same letter, in the line, differ by the test of Tukey $(\mathrm{p} \leq 0.05)$.

\section{DISCUSSION}

\section{N Doses}

The response to nitrogen fertilization for height and diameter at breast height of plants was the same in both forest species, indicating the maximum technical efficiency dose of $47 \mathrm{~kg} \mathrm{ha}^{-1}$ of $\mathrm{N}$ in the average of the two evaluated parameters. Probably, the low organic matter content of the soil $\left(22 \mathrm{~g} \mathrm{dm}^{-3}\right)$ was not capable of mineralize enough $\mathrm{N}$ to meet plants demand. Responses to the application of $\mathrm{N}$ in forest species are found in several studies, but with great variation in increment an in maximum growth dose. In a study conducted in Quartzipsamment with low content of organic matter, Gazola et al. (2015) found 5\% increment on the diameter at breast height in clone of E. urophylla at 18 months of age with dose of $63 \mathrm{~kg} \mathrm{ha}^{-1}$ of N. Larger increases, from $42 \%$ in clone stem volume from the same forest species, were obtained by Jesus et al. (2012) in a Oxisol of very argillaceous texture and with 
high content of organic matter $\left(51 \mathrm{~g} \mathrm{dm}^{-3}\right)$ within 30 months from planting, with the dose of $74 \mathrm{~kg} \mathrm{ha}^{-1}$.

Regarding the culture of Australian cedar, the amount of information on the nitrogen fertilizer in field cultivation is limited. In an experiment with Quartzipsamment, with low organic matter content $\left(16 \mathrm{~g} \mathrm{dm}^{-3}\right)$, Moretti et al. (2015) found response to nitrogen fertilization for plants height, at 12 months of age, up to the maximum amount of $\mathrm{N}$ applied ( $250 \mathrm{~g}_{\text {plant }}^{-1}$, equivalent to $416 \mathrm{~kg} \mathrm{ha}^{-1}$ of $\mathrm{N}$ ), with an increase of $20 \%$ compared to treatment without fertilizing nitrogen. The authors point out that high doses of $\mathrm{N}$ are not economically viable in commercial cultivation and studies on doses of maximum economic efficiency are important to adequate the nitrogen fertilization.

The increase variation of eucalyptus plants growth and the dose of maximum response in regard to the nitrogen fertilization in different studies may be related to the type of soil, time of cultivation and climatic conditions of each region. The response to the nitrogen fertilization is bigger in younger plants e depends on the total amount of $\mathrm{N}$ and of the $\mathrm{N}$ capable of mineralization from the soil (SANTANA et al., 2008). In grounds with high $\mathrm{N}$ mineralization rate, the response to the nitrogen fertilization tends to be small or absent and, in soil with low mineralization rate, the reply tends to be bigger, even if the ground presents high content of organic matter (GAMA-RODRIGUES et al., 2005).

It is observed that the maximum doses of technical efficiency of $\mathrm{N}$ to the plant height and diameter at breast height was lower than recommended for the Australian cedar and eucalyptus (CQFS-RS/SC, 2016). The Commission indicates applying, in soils with low organic matter content $\left(\leq 25 \mathrm{~g} \mathrm{dm}^{-3}\right), 45 \mathrm{~kg} \mathrm{ha}^{-1}$ of N for planting and $45 \mathrm{~kg} \mathrm{ha}^{-1}$ of $\mathrm{N}$ for the fertilization of cultures growth of Australian cedar and eucalyptus. It should be noted that the Commission recommends the application of fertilizer growth between 3 and 6 months, like that used in the experiment, since there is a low response to fertilization after this period, even in soil with low organic matter content.

The maximum height and diameter at breast height growth of Australian cedar and eucalyptus plants with the lowest $\mathrm{N}$ dose, in relation to the dose recommended by CQFS-RS/SC (2016), may be related to the type of cultivation prior to the planting of the species forests. Mineralization of organic $\mathrm{N}$ from soil organic matter and of the invasive plants waste that have accumulated during the period of cultivation (three years) may have answered part of the need for $\mathrm{N}$ of plants, even in soil with low organic matter content. In that matter, the inclusion of other parameters of nitrogen fertilizer, such as the use of soil mineral $\mathrm{N}$ content as additional indicator, can contribute to the adequacy of the $\mathrm{N}$ doses for the forest species, in a similar way to the proposal of Rambo et al. (2007) for the cultivation of corn. Furthermore, the suitability of $\mathrm{N}$ dose according to the type of culture antecedent of seedling planting. Also, its dry matter production of this culture can enhance the recommendation of $\mathrm{N}$ to the forest species, as used for recommendation of nitrogen fertilization on crops of maize and wheat (CQFS-RS/SC, 2016).

When comparing the two-forest species, there was greater plant height growth and diameter at breast height from eucalyptus. Plant height differences between the two species were lower in the early evaluations conducted after planting, increased gradually in subsequent reviews, probably due to the decrease in temperature from the month of May, affecting, with greater intensity, plant growth Australian cedar (BLAGITZ et al., 2016). Nevertheless, both species showed suitable initial growth in the climate and soil conditions in which the experiment was conducted.

It is observed that the foliar $\mathrm{N}$ concentration of eucalyptus plants is above the range of sufficiency of 15.0 and $20.0 \mathrm{~g} \mathrm{~kg}^{-1}$ established by CQFS-RS/SC (2016). The high foliar concentrations of N, even in the absence of nitrogen fertilization, indicate the need to revise the values of the appropriate range for this nutrient in the conditions of the southern region of Brazil and to establish ranges according to age of the plant, species and eucalyptus clones. In the case of Australian cedar, the value was lower than the one found in the work of Moretti et al. (2015) at 10 months of age $\left(31.4 \mathrm{~g} \mathrm{~kg}^{-1}\right.$ of $\left.\mathrm{N}\right)$. The authors also did not observe response to nitrogen fertilization on foliar nutrient levels at doses of up to $250 \mathrm{~g} \mathrm{pit}^{-1}$ of $\mathrm{N}$, despite the significant increase in height and in the lab diameter with the use of fertilization, like those obtained in this study.

This information indicates that the Australian cedar could demand in N, as for Moretti et al (2011) in cultivation of seedlings during the same time period after transplantation in vases filled with Oxisol. Further information on field cultures with nutritional assessment at different ages are necessary to define the nutritional requirement and help to delimit the range of sufficiency for this forest species.

\section{P Doses}

The lack of response to doses of $\mathrm{P}$ in plants height, diameter at breast height and foliar nutrient concentration is probably associated with the high content of $\mathrm{P}$ in the soil of the experimental area $\left(4.9 \mathrm{mg} \mathrm{dm}^{-3}\right)$, value above the critical level for the cultivation of forest species (CQF S-RS/SC, 2016). The availability of P above the critical level is enough to meet the nutrient requirement of plants, especially in the early stages of growth, when the demand for nutrients is greater (SANTANA et al., 2008).

It is worth noting that CQFS-RS/SC (2016) reclassified the P values in the soil, reducing critical levels in

FLORESTA, Curitiba, PR, v. 49, n. 1, p. 001-010, jan/mar 2019

Da Ros. C. O et.al.

ISSN eletrônico 1982-4688

DOI: 10.5380 / rf.v49 i1.51174 
relation to the previous edition (CQFS-RS/SC, 2004) due to the lower nutritional requirement of forest species compared to annual cultures destined to the production of grain. Thus, the original value of $\mathrm{P}$ in the soil, at the time of the experiment installation $\left(4.9 \mathrm{mg} \mathrm{dm}^{-3}\right.$ of $\mathrm{P}$ ), went from "medium" to "high". This alteration may justify the absence of response to $\mathrm{P}$ doses on plant growth of both forest species under the soil conditions in which the experiment was conducted, since the response to phosphate fertilization normally occurs when the $\mathrm{P}$ content in the soil is below the critical level (very low, low or medium content).

The response to phosphate fertilization with $\mathrm{P}$ levels below the critical level is reported in various seedling cultivation and field conditions, such as species T. ciliata E. dunnii, E. benthamii and E. urograndis (MORETTI et al., 2011; DIAS et al., 2014; GAZOLAt al., 2015; MORETTI et al., 2015). In field cultures, height increases may reach $19 \%$ with application of $200 \mathrm{~kg} \mathrm{ha}^{-1}$ of $\mathrm{P}_{2} \mathrm{O}_{5}$ in eucalyptus (GAZOLA et al., 2015) and of 17\% with use of $219 \mathrm{~g} \mathrm{pit}^{-1}$ of $\mathrm{P}_{2} \mathrm{O}_{5}$ in Australian cedar (MORETTI et al., 2015).

The CQFS-RS/SC (2016) recommends the use of maintenance fertilization in the cultivation of forest species in soils with a $\mathrm{P}$ content above the critical level, with application of $40 \mathrm{~kg} \mathrm{ha}^{-1}$ of $\mathrm{P}_{2} \mathrm{O}_{5}$ in the planting of Australian cedar seedlings and of $50 \mathrm{~kg} \mathrm{ha}^{-1}$ of $\mathrm{P}_{2} \mathrm{O}_{5}$ in the eucalyptus plantation. This dose is important to maintain the proper content of nutrient in the soil due to losses in the system and exportation after withdrawal of the wood. Silva et al. (2012) highlight that the quantity exported by the trunk (bark and wood) varies between species and age of the plants. For the eucalyptus, CQFS-RS/SC (2016) indicates applying $1.0 \mathrm{~kg} \mathrm{ha}^{-1} \mathrm{P}_{2} \mathrm{O}_{5}$ for each extra unit of wood produced over $40 \mathrm{~m}^{3} \mathrm{ha}^{-1}$ year $^{-1}$.

The absence of response to phosphate fertilization did not allow to evaluate possible differences in nutritional requirement of $\mathrm{P}$ between the Australian cedar and eucalyptus plants. Experiments in conditions of low nutrient availability in the soil are necessary to delimit doses of phosphate fertilization, because the response to phosphate fertilization is different between the forest species, as highlighted in the work of Fontes et al. (2013) with Swietenia macrophylla, Mimosa caesalpiniaefolia, Cedrela fissilis and T. ciliata and Dias et al. (2014) with species of eucalyptus (E. benthamii and E. dunnii).

Webb et al. (2000) report that there are significant differences in the ability of tropical tree species to acquire and use phosphorus. Consequently, the application of phosphate fertilization is often inefficient, regardless of the type of soil or forest species. The ability of association of the forest species with arbuscular mycorrhizal fungi is also a factor that can contribute to the nutrient supply of plants, depending on the conditions of phosphorus availability in the soil (SILVA et al., 2017).

Foliar P concentration found in eucalyptus is next to the upper fill range recommended by CQFS-RS/SC (2016) (1.0 to $1.3 \mathrm{~g} \mathrm{~kg}^{-1}$ ). This information reinforces again that there was no nutrient limitation in the soil, justified by the original soil contents within the appropriate range $\left(4.9 \mathrm{mg} \mathrm{dm}^{-3}\right.$ of $\left.\mathrm{P}\right)$ and absence of response on the growth of eucalyptus plants.

Eucalyptus and Australian cedar studies show that, despite the answer in height and in diameter with increasing doses of $\mathrm{P}$, there is no variation in foliar nutrient concentrations. In a study with eucalyptus, Gazola $e t$ al. (2015) found, in a Quartzipsamment, with "very low" level of P, $1.2 \mathrm{~g} \mathrm{~kg}^{-1}$ on the leaves within 18 months of culture, less than the average concentration of this study, where there was leaves collection 8 months within planting in the field. Meanwhile, in a study with Australian cedar, Moretti et al. (2015) found, in an Oxisol, with "very low" of P, the foliar P concentration of $1.9 \mathrm{~g} \mathrm{~kg}^{-1}, 10$ months after planting in the field, regardless of the dose of phosphate fertilization used. These data were also lower than those of the present study.

The variation of foliar $\mathrm{P}$ concentrations among the works shows a need for more studies towards delimitation of sufficiency ranges according to the age and part of the plants. Only then it will be possible for the result of the foliar analysis to be used with greater security in monitoring the nutritional quality of forest cultures. The CQFS-RS/SC (2016) indicates the range of sufficiency of foliar nutrients only for Eucalyptus and Pinus and points out that the interpretation of the data must be made carefully, based on the restricted amount of regional research data.

The largest foliar concentrations of $\mathrm{P}$ in Australian cedar in comparison to the eucalyptus underscores the greater nutritional requirement of Australian cedar, like the experiment with $\mathrm{N}$ doses. Although nutrient concentrations are greatest in the Australian cedar, Ares and Fownes (2000) highlight that the contents of N per leaf area unit were like those of eucalyptus. Moretti et al. (2011) reported that the Australian cedar is responsive to the addition of nutrients, being the nutritional demand bigger for $\mathrm{P}$, followed by $\mathrm{N}>\mathrm{S}>\mathrm{Ca}>\mathrm{K}>\mathrm{Mg}>\mathrm{Cu}$.

Comparing the height growth of the plant of both forest species and literature data with similar ages, it is observed that, in the eucalyptus, the value was $1.4 \mathrm{~m}$ lower than the obtained by Gazola et al. (2015), with clone of E. urograndis. In the Australian cedar, the height was lower in $0.8 \mathrm{~m}$ than obtained by Moretti et al. (2015). This can be justified by the lower air temperature in the subtropical region of southern Brazil, what was probably one of the factors for the lower rate of growth of the two-forest species in comparison to the data from the tropical climate of the center of the country (MACHADO et al., 2014). It is highlighted that the frosts that occurred in the 
experimental area were of low frequency and intensity in the autumn and winter of 2014. Lower temperatures in some years can damage the growing points of the tops of the plants and affect, with greater intensity, mainly the growth of Australian cedar, which is a forest species less adapted to these conditions when compared to the eucalyptus. Therefore, larger studies with forest species need to be carried out in order to assess the initial and long-term growth for the recommendation on commercial cultivation in southern Brazil.

\section{CONCLUSIONS}

- Nitrogen fertilization contributes to the increase of the initial growth in height and diameter of the plants of Toona ciliata and Eucalyptus grandis, with maximum efficiency in the dose of $47 \mathrm{~kg} \mathrm{ha}^{-1}$ of nitrogen.

- Phosphate fertilization does not increase the initial growth of Toona ciliata and Eucalyptus grandis, which may be related to the appropriate phosphorus levels in the soil in which the experiment was conducted.

- Nitrogen and phosphate fertilization do not contribute to increased foliar concentrations of nitrogen and phosphorus in both forest species. The concentrations of these nutrients were larger in Toona ciliata, indicating greater nutritional requirement compared to Eucalyptus grandis.

\section{ACKNOWLEGDMENTS}

The authors gratefully acknowledge the financial support of the Fund of Research Incentive (FIPE) at the Federal University of Santa Maria.

\section{REFERENCES}

ABRAF - Associação Brasileira de Produtores de Florestas Plantadas. Anuário estatístico da ABRAF 2013 ano base 2012. Brasília: ABRAF, 2013. 148p. Disponível em: <https://goo.gl/NNd2ux>. Acesso em 28 de agosto de 2015.

ALVARES, C. A.; STAPE, J. L.; SENTElHAS, P. C.; GONÇALVES, J. L. M.; SPAROVEK, G. Köppen's climate classification map for Brazil. Meteorologiesche Zeitschrift, Stuttgart, v. 22, p. 711-728, 2013.

ARES, A.; FOWNES J. H. Productivity, nutrient and water-use efficiency of Eucalyptus saligna and Toona ciliata in Hawaii. Forest Ecology and Management, v. 139, n. 3, p. 227- 236, 2000.

BLAGITZ, M.; BOTOSSO, P. C.; BIANCHINI, E.; MEDRI. M. E. Periodicidade do crescimento de espécies arbóreas da Floresta Estacional Semidecidual no Sul do Brasil. Scientia Forestalis, Piracicaba, v. 44, n. 109, p. 163-173, 2016.

BRAGA, M. M.; FURTINI NETO, A. E.; OLIVEIRA, A. H. Influência da saturação por bases na qualidade e crescimento de mudas de cedro-australiano (Toona ciliata M. Roem var. australis). Ciência Florestal, Santa Maria, v. 25, n. 1, p. 49-58, 2015.

CQFS-RS/SC - COMISSÃO DE QUÍMICA E FERTILIDADE DO SOLO. Manual de adubação e de calagem para os Estados do Rio Grande do Sul e de Santa Catarina. 10.ed. Porto Alegre: Sociedade Brasileira de Ciência do Solo/Núcleo Regional Sul, 2004. 400p.

CQFS-RS/SC - COMISSÃO DE QUÍMICA E FERTILIDADE DO SOLO. Manual de calagem e adubação para os Estados do Rio Grande do Sul e de Santa Catarina. 11.ed. Frederico Westphalen: Sociedade Brasileira de Ciência do Solo/Núcleo Regional Sul, 2016. 376p.

DIAS, L. P. R.; GATIBONI, C. L.; BRUNETTO, G.; SIMONETE, M. P.; BICARATTO, B. Eficiência relativa de fosfatos naturais na adubação de plantio de mudas de Eucalyptus dunnii Maiden e Eucalyptus benthamii Maiden et cambage em solo sem e com calagem. Ciência Florestal, Santa Maria, v. 25, n. 1, p. 37-48, 2015.

FERREIRA, D. F. Sisvar: A computer statistical analysis system. Ciência e Agrotecnologia, Lavras, v.35, n.6, p.1039-1042, 2011.

FONTES, A. G.; GAMA-RODRIGUES, A. C.; GAMA-RODRIGUES, E. F. Eficiência nutricional de espécies arbóreas em função da fertilização fosfatada. Pesquisa Florestal Brasileira, Colombo, v. 33, n. 73, p. 09-18, 2013.

GAMA-RODRIGUES, E. F.; BARROS, N. F.; GAMA-RODRIGUES, A. C.; SANTOS, G. A. Nitrogênio, carbono e atividade da biomassa microbiana do solo em plantações de eucalipto. Revista Brasileira de Ciência do Solo, Viçosa, n. 29, v. 6, p. 893-901, 2005.

FLORESTA, Curitiba, PR, v. 49, n. 1, p. 001-010, jan/mar 2019

Da Ros. C. O et.al.

ISSN eletrônico 1982-4688

DOI: 10.5380 / rf.v49 i1.51174 
GAZOLA, R, N.; BUZETTI, S.; TEIXEIRA FILHO, M. C. M.; DINALli, R. P.; MORAES, M. L. T.; CELESTRINO, T. S.; SILVA, P, H. M.; DUPAS, E. Doses of N, P and K in the cultivation of eucalyptus in soil originally under Cerrado vegetation. Semina: Ciências Agrárias, Londrina, v. 36, n. 3, suplemento 1, p. 1895$1912,2015$.

GUARDINI, R.; COMIN, J. J.; SANTOS, D.; GATIBONI, L. C.; TIECHER. T.; SCHMITT, D.; BENDER, M. A.; BELLI FILHO, P.; OLIVEIRA, P. A. V.; BRUNETTO, G. Phosphorus accumulation and pollution potential in a hapludult fertilized with pig manure. Revista Brasileira de Ciência do Solo, Viçosa, v. 36, n. 4, p. 1333$1342,2012$.

JESUS, G. L.; BARROS, N. F.; SILVA, I. R.; NEVES, J. C. L.; HENRIQUES, E. P.; LIMA, V. C.; FERNANDES, L. V.; SOARES, E. M. B. Doses e fontes de nitrogênio na produtividade do eucalipto e nas frações da matéria orgânica em solo da região do cerrado de Minas Gerais. Revista Brasileira de Ciência do Solo, Viçosa, v. 36, n. 1 , p. 201-214, 2012.

MACHADO, S. A.; ZAMIN, N. T.; NASCIMENTO, R. G. M.; SANTOS, A. A. P. Efeito de variáveis climáticas no crescimento mensal de Pinus taeda e Araucaria angustifolia em fase juvenil. Floresta e Ambiente, Seropédica, v. 21, n. 2, p. 170-181, 2014.

MORETTI, B. S.; FURTINI NETO, A.E.; PINTO, S. I. C.; FURTINI, I. V.; MAGALHÃES, C. A. S. Crescimento e nutrição mineral de mudas de cedro australiano (Toona ciliata) sob omissão de nutrientes. Cerne, Lavras, v. 17 , n. 4, p. 453-463, 2011.

MORETTI1, B. S.; FURTINI NETO, A. E.; BENATTI, B. P.; DECCETTI, S.; LACERDA, J. J. J.; STEHLING, E. C. Nitrogen, potassium and phosphorous fertilizer suggestions for australian red cedar in Oxisol. Floresta, Curitiba, v. 45, n. 3, p. 599-608, 2015.

RAMBO, L.; SILVA, P. R. F.; BAYER, C.; ARGENTA, G.; STRIEDER, M. L.; SILVA, A. A. Teor de nitrato como indicador complementar da disponibilidade de nitrogênio no solo para o milho. Revista Brasileira de Ciência do Solo, Viçosa, v. 31, n. 4, p. 731-738, 2007.

SANTANA, R. C.; BARROS, N. F.; NOVAIS, R. F.; LEITE, H. G.; COMERFORD, N. B. Alocação de nutrientes em plantios de eucalipto no Brasil. Revista Brasileira de Ciência do Solo, Viçosa, v. 32, p. 2723-2733, 2008.

SANTOS, H. G. Sistema brasileiro de classificação de solos. 3. ed. Brasília: Embrapa Solos, 2013. 353 p.

SILVA, E. P.; FERREIRA, P. A. A.; FURTINI-NETO, A. E.; FONSÊCA, C. R.; SOARES, S. Micorrizas arbusculares e fosfato no desenvolvimento de mudas de cedro-australiano. Ciência Florestal, Santa Maria, v. 27 , n. 4, p. 1269-1281, 2017.

SILVA, F. C. Manual de análises químicas de solos, plantas e fertilizantes. 2. ed. Brasília: Embrapa Informação Tecnológica, 2009. 627 p.

SILVA, J. V.; NOGUEIRA, G. S.; SANTANA, R. C.; LEITE, H. G.; OLIVEIRA, M. L. R.; ALMADO, R. P. Produção e acúmulo de nutrientes em povoamento de eucalipto em consequência da intensidade do desbaste e da fertilização. Pesquisa Agropecuária Brasileira, Brasília, v. 47, n. 11, p. 1555-1562, 2012.

VILELA, E. S.; STEHLING, E.C. Recomendações de plantio para cedro australiano. Bela Vista Florestal: Campo Belo, 2012. 23p.

WEBB, M. J.; REDDELL, P.; HAMBLETON, A.; ROBSON, K. Growth response of four tropical plantation timber species to increasing phosphorus supply and assessment of phosphorus requirements using foliar analysis. New Forests, v. 20, n. 2, p. 193-211, 2000 